\title{
Erken Evre Dudak Kanserlerinde Boyuna Yaklaşım
}

\author{
Approachment to Neck in Early Stage Lip Cancers
}

Deniz Demir, Sena Genç, Mehmet Güven, Mahmut Sinan Yllmaz, Ahmet Kara

Sakkarya Üniversitesi Tıp Fakültesi, Kulak Burun Boğaz ve Baş Boyun Cerrahisi Anabilim Dalı, Sakarya,

Correspondence / Yazışma Adresi:

Doç. Dr. Deniz DEMiR

Sakarya Üniversitesi Tıp Fakültesi, Kulak Burun Boğaz Ve Baş Boyun Cerrahisi AD. Sakarya

T: 05055784126

E-mail: drdenizdemir@hotmail.com

Geliş Tarihi / Received : 02.12.2017

Kabul Tarihi / Accepted : 22.12.2017

\section{Özet}

Amaç: Bu çalışmanın amacı, erken evre dudak kanseri hastalarında, bekle-gör politikasının ve boyun diseksiyonununprognoz üzerindeki rolünü araştırmaktır.

Yöntem: Mart 2007 - Nisan 2015 yılları arasında T1-2N0 alt dudak kanseri nedeniyle primer bölge ve boyun cerrahisi yapılan 20 hasta (5 kadın, 15 erkek; yaş ortalaması 62.64 yıl; $38-80$ yaş aralığı) çalışmaya dahil edildi. Klinik özellikler, lezyonun lokalizasyonu, bölgesel lenf nodu durumu, tümör evrelemesi, cerrahi tedavi sonuçları ve patolojik inceleme verileri geriye dönük olarak incelendi. Tüm olgularda $1 \mathrm{~cm}$ cerrahi sınırla tümör eksize edildi. Doku defekti birincil kapatma ya da çeşitli rekonstriksiyonteknikleri ile onarıldı. Tüm T2N0 evre hastalara boyun diseksiyonu uygulandı. Tümör dudağın ortasında yer alıyorsa, bilateral boyun diseksiyonu, aksi taktirde tek taraflı boyun diseksiyonu yapıldı.

Bulgular: Her olguda histopatolojik tanı skuamöz hücreli karsinomdu. Ortalama izlem süresi 45.82 ay idi. Klinik olarak T1N0 tümörü tanısı konan 15 hasta ve klinik olarak T2N0 tümörü tanısı konan 5 hasta vardı. T1N0 tümörleri için 3 suprahyoid, 2 bilateralsupraomohyoid boyun diseksiyonu yapıldı. Üç T2N0 tümöründe supraomohyoid boyun disseksiyonubilateral olarak yapıldı ve geriye kalan 2 hastadasuprahyoid boyun diseksiyonu yapıldı.

Sonuç: Hastalıksız dört yıllık sağ kalım oranları, erken evre dudak kanseri vakalarında belirgin olarak daha yüksekti. Sonuçlarımız T1N0 alt dudak kanserlerinde boyun diseksiyonunun gerekli olmayabileceğini göstermektedir. ( Sakarya Tıp Dergisi 2017, 7(4):184-187)

Anahtar Kelimeler: Dudak kanseri; Erken evre; Boyun Diseksiyonu

\section{Abstract}

Objective: The aim of this study is to investigate the role of neck dissection and wait-see policy for the neck treatment on prognosis of the patients with early stage lip cancer.

Method: The study included 20 patients of T1-2N0 lower lip cancer ( 5 females, 15 males; mean age 62.64 years; range 38 to 80 years) who underwent surgery for primary site and neck between March 2007 and April 2015 . Data were reviewed retrospectively on clinical features, localization of the lesions, regional lymph node status, tumor staging, results of surgical treatment and pathological examination. Tumors were excised with $1 \mathrm{~cm}$ tumor free surgical margin in all cases. The tissue defect was reconstructed by primary closure or varied reconstruction techniqeus. All patients with T2N0 stage underwent neck dissection. If the tumor was located in the middle of the lip, bilateral neck dissection, otherwise unilateral neck dissection was performed.

Results: Histopathologic diagnosis was squamous cell carcinoma in all cases. The mean follow-up period was 45.82 months. There were 15 patients with clinically diagnosed T1N0 tumors and 5 patients with clinically diagnosed T2N0 tumors. For the patients with T1N0 tumors, 3 suprahyoid, 2 bilateral supraomohyoid neck dissections were performed. Supraomohyoid neck dissection was performed bilaterally in 3 patiens with T2N0 tumors, and suprahyoid neck dissection was performed in remaing 2 patients.

Conclusion: Disease-free four-year survival rates were significantly higher in the patients with early stage lip cancer. Our results present that neck dissection may not be necessary in patients with T1N0 lower lip cancers. ( Sakarya Med J 2017, 7(4):184-187 )

Keywords Lip cancer; Early stage; Neck Dissection 


\section{Introduction}

Lip carcinoma is the most frequent cancer in head and neck region, and account for $25 \%$ to $30 \%$ of all oral cavity cancer. Almost $95 \%$ of lip cancers are squamous cell carcinoma and $90 \%$ emergefrom the lower lip. ${ }^{1}$ The main risk factor for the lip cancer is ultraviolet radiation exposure. Chronic alcoholism, pipe cigarette smoking, and poor oral hygiene may contribute to its development. ${ }^{2}$

Early stage lip cancers constitute of $\mathrm{T} 1$ and $\mathrm{T} 2$ stage cancer with clinically negative neck metastases. Neck metastasis is the most important prognostic factor in the lip cancers. Surgical excision of the primary lesion and neck dissection are the gold standard for the treatment of this type of carcinoma in case of neck metastases. Currently there is no international or national consensus relating prophylactic neck dissection for early stage lip carcinoma. The purpose of the study was to investigate the role of neck dissection and wait-see policy for neck treatment on prognosis of patients with early stage lip cancer.

\section{Materials and Methods}

The research protocol was approved by the Research Ethics Comittee of Sakarya University School of Medicine. A retrospective study was conducted on 20 medical records of patients with T1-T2 N0 lip cancers. These patients attended our department of otolaryngology for surgery treatment from 2007 to 2015. Patients previously submitted to surgical and non-surgical treatment, cases of recurrens of primary tumour, and patients who were not followed up for at least two years were our exlcusion criterias. Otolaryngologic examination and computerized tomography were used for staging of the tumor and the neck with regard to TNM lassification of the American Joint committee on Cancer (AJCC). Data regarding to type of surgery, clinical stage of lesion and histological results and follow-up time were extracted from their medical records. Postoperative follow-up period was every 3 months for first year, and 6 months for second year.

\section{Results}

Fifteen (75\%) male and 5 female(25\%) patients were included into the study. They ranged in age from 38 to 80 years at the time of admission. No postoperative complication was defined.
The mean follow-up period was 45.82 months. Histopathologic diagnosis was squamous cell carcinoma in all cases. There were 15 patients with T1N0 tumors and 5 patients with T2N0 tumors. For T1N0 tumors, 3 suprahyoid, 2 bilateral supraomohyoid neck dissections were performed. Supraomohyoid neck dissection was performed in bilaterally in 3 T2N0 tumors, and suprahyoid neck dissection was performed in remaing 2 tumors. Table 1 shows distribution of all patients in this study. After pathological examination, neck node metastases was detected in only one patient with T2N0 tumor. No recurrence was detected in all 20 patients.

\begin{tabular}{|c|c|c|c|}
\hline \multicolumn{4}{|c|}{ Table 1. Distribution of patients with lip cancer } \\
\hline & Neck dissection & $\begin{array}{c}\text { Wait - see } \\
\text { policy }\end{array}$ & Neck metastasis \\
\hline T1 & $\begin{array}{c}\text { 3 suprahyoid, } \\
\text { 2 bilateral supraomohyoid }\end{array}$ & 10 & 0 \\
\hline T2 & $\begin{array}{c}\text { 2 suprahyoid, } \\
3 \text { bilateral supraomohyoid }\end{array}$ & 0 & 1 \\
\hline
\end{tabular}

\section{Discussion}

There is still no consensus in the literature regarding approach to neck for clinically-negative neck node in patients with early stage lip cancers. The reported incidence of neck node metastases ranges from $0 \%$ to $15 \%$ for $\mathrm{T} 1$ cancers and $11 \%$ to $35 \%$ for T2 cancers. ${ }^{3}$ In addition, the literature indicates that prophylactic neck dissection should be performed when the risk of occult metastasis is $20 \%$ or more. ${ }^{4}$ Therefore, the arguments for not performing elective neck dissection include early stage lip cancers for the low metastatic rates. In this study, our results are consistent with the literature. Whereas no neck metastasis was detected in T1 lip cancer group, only one patient had occult neck metastasis in T2 lip cancer group (Table 1).

Early stage lip cancers can be treated equally by surgery or radiotherapy and cure rates are rather high, ranging from $83 \%$ to $96 \% .{ }^{5}$ However, surgery is the most acceptable modality for most patients because of the advantage of margin assessment, avoidance of radiotherapy complication, rapid rehabilitation and better cosmetic results. ${ }^{6}$ There is almost consensus regarding treatment of primary lesion but it is not clear when neck dissection should be performed and what level should be considered. In the case 
with clinically palpable lymph node supraomohyoid neck dissection (level I to III) or comprehensive neck dissection (level I to IV) is usually proposed. ${ }^{6}$ However, not all clinically enlargement of lymph node includes malignant cells. Inflammatory or hyperplastic changes in lymph nodes may cause to overtreatment in most patients. In our study, 5 patients in T1 and 5 patients in T2 groups had underwent prophylactic neck dissection and the rates of positive lymph nodes were determined $0 \%$ and $20 \%$ respectively in both groups. No recurrence occurred within almost four -year of follow-up period in 15 patients with T1N0 lip cancer.

Vanderlei at al. considered that in which tumor size a prophylactic neck dissection would be indicated in T2N0 lip cancers. They showed that prophylactic neck dissection is indicated for tumors larger than $3 \mathrm{~cm} .7$ They observed that tumor measuring less than $3 \mathrm{~cm}$ presented a rate of late metastases of $9 \%$, while tumors of more than $3 \mathrm{~cm}$ presented a rate of late metastases of $43.9 \%$. However, according to Bucur et al. because of much poorer diagnosis when associated with cervical node metastases, prophylactic lymph node dissection is beneficial in patients with early stage lip cancer. ${ }^{8}$

\section{Conclusion}

Our study results showed that neck dissection may not be necessary in patients with T1N0 lower lip cancers, however close followup is mandatory. 
1. Morselli P, Masciotra L, Pinto V, Zollino I, Brunelli G, Carinci F. Clinical parameters in T1N0M0 lower lip squamous cell carcinoma. J Craniofac Surg. 2007; 18(5):1079-1082.

2. Baker SR. Risk factors in multiple carcinomas of the lip. Otolaryngol Head Neck Surg (1979). 1980;88(3):248-251.

3. de Visscher JG, van den Elsaker K, Grond AJ, van der Wal JE, van der Waal I. Surgical treatment of squamous cell carcinoma of the lower lip: evaluation of long-term results and prognostic factors--a retrospective analysis of 184 patients. J Oral Maxillofac Surg. 1998;56(7):814-820.

4. Onerci M, Yilmaz T, Gedikoğlu G. Tumor thickness as a predictor of cervical lymph node metastases in squamous cell carcinoma of the lower lip. Otolaryngol Head Neck Surg. 2000 ;122(1):139-142.

5. Baker SR, Krause C). Carcinoma of the lip. Laryngoscope. 1980;90(1):1927.

6. Guney E, Yigitbasi OG. Functional surgical approach to the level I for staging early carcinoma of the lower lip. Otolaryngol Head Neck Surg. 2004;131(4):503-508.

7. Vanderlei JP, Pereira-Filho FJ, da Cruz FA, de Mello FL, Kruschewsky Lde $\mathrm{S}$, de Freitas LC, at al. Management of neck metastases in T2N0 lip squamouz cell carcinoma. Am J Otolaryngol. 2013;34(2):103-106.

8. Bucur A, Stefanescu L. Management of patients with squamous cell carcinoma of the lower lip and N0-neck. J Craniomaxillofac Surg. 2004;32(1):16-18

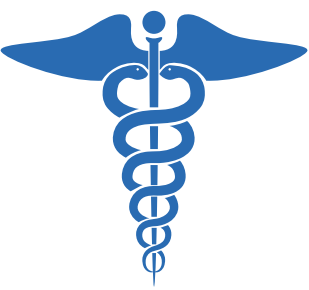

